Published in final edited form as:

Curr Hypertens Rep. 2013 December ; 15(6): 694-702. doi:10.1007/s11906-013-0390-z.

\title{
Dietary Approaches to Prevent Hypertension
}

\author{
Lydia A. Bazzano, \\ Department of Epidemiology, Tulane University School of Public Health \& Tropical Medicine, 440 \\ Canal St, New Orleans, LA 70112, USA. Department of Hospital Medicine, Ochsner Medical \\ Center, 1514 Jefferson Highway, New Orleans, LA 70121, USA

\section{Torrance Green,} \\ Department of Physiology, Tulane Hypertension and Renal Center of Excellence, New Orleans, \\ LA 70112, USA. Department of Internal Medicine, Ochsner Clinic Foundation, New Orleans, LA \\ 70121, USA
}

Teresa N. Harrison, and

Department of Research \& Evaluation, Kaiser Permanente Southern California, 100 South Los

Robles, 2nd Floor, Pasadena, CA 91101, USA

\section{Kristi Reynolds}

Department of Research \& Evaluation, Kaiser Permanente Southern California, 100 South Los

Robles, 2nd Floor, Pasadena, CA 91101, USA

Lydia A. Bazzano: LBazzano@tulane.edu; Torrance Green: torgreen@ochsner.org; Teresa N. Harrison:

Teresa.N.Harrison@kp.org; Kristi Reynolds: Kristi.Reynolds@kp.org

\section{Abstract}

Elevated blood pressure arises from a combination of environmental and genetic factors and the interactions of these factors. A substantial body of evidence from animal studies, epidemiologic studies, meta-analyses, and randomized controlled trials has demonstrated that certain dietary patterns and individual dietary elements play a prominent role in the development of hypertension. Changes in diet can lower blood pressure, prevent the development of hypertension, and reduce the risk of hypertension-related complications. Dietary strategies for the prevention of hypertension include reducing sodium intake, limiting alcohol consumption, increasing potassium intake, and adopting an overall dietary pattern such as the DASH (Dietary Approaches to Stop Hypertension) diet or a Mediterranean diet. In order to reduce the burden of blood pressure-related complications, efforts that focus on environmental and individual behavioral changes that encourage and promote healthier food choices are warranted.

(C) Springer Science+Business Media New York 2013

Correspondence to: Kristi Reynolds, Kristi. Reynolds@kp.org.

Conflict of Interest Lydia A. Bazzano, Torrance Green, Teresa N. Harrison, and Kristi Reynolds declare that they have no conflict of interest.

Compliance with Ethics Guidelines

Human and Animal Rights and Informed Consent This article does not contain any unpublished studies with human or animal subjects performed by any of the authors. 


\section{Keywords}

Hypertension; High blood pressure; Prevention; Diet; Fruits and vegetables; Dietary patterns; Macronutrients; Micronutrients; Sodium; Potassium; Magnesium; Calcium; Alcohol; Fiber; Functional foods

\section{Introduction}

Hypertension exerts a staggering worldwide burden on human quality of life and health care system resources via contribution to increased mortality and risk of cardiovascular diseases such as myocardial infarction, angina pectoris, heart failure, and stroke [1,2]. In the US, hypertension is the most common primary diagnosis with 35 million outpatient office visits annually [3]. Based on data from 2007 to 2010 , over $\$ 50$ billion is spent in treating one of every three adults 20 years of age or older in the US who have hypertension and costs continues to rise [1, 2]. Among the estimated 78 million US adults with hypertension, $82 \%$ are aware of their condition, and $75 \%$ of those diagnosed with hypertension are managed with antihypertensive medications [1]. Unfortunately, successful reductions to recommended blood pressure goals are obtained in only $53 \%$ of those with documented hypertension [4].

Even a small downward shift in the distribution of blood pressure in the general population could have a substantial impact on the risk of cardiovascular disease. A 2- mmHg reduction in the population average of diastolic blood pressure could be expected to result in a $17 \%$ reduction in the prevalence of hypertension, a $6 \%$ reduction in the risk of coronary heart disease, and a $15 \%$ reduction in the risk of stroke [5].

Dietary modifications have been widely regarded as a lifestyle modification strategy with enormous potential for preventing hypertension at a cost that is often less than current pharmacologic interventions. Such successful historical interventions are reflected in dietary recommendations advocating weight loss, reduced intake of dietary sodium, and moderation in alcohol consumption, and more recently revised to reflect the blood-pressure lowering effect of potassium supplementation and a dietary eating pattern [4]. This article reviews the consistency of blood pressure results regarding proven dietary interventions as well as several new dietary targets.

\section{Dietary Patterns}

\section{DASH Diet}

One of the most well-known dietary strategies for lowering blood pressure is the Dietary Approaches to Stop Hypertension (DASH) pattern [6], which significantly reduced blood pressure among normotensives as well as those with hypertension [7]. The DASH dietary pattern, which emphasizes a diet rich in fruits, vegetables, and low-fat dairy products and reduced saturated and total fat, has been tested in multiple randomized controlled trials in specific populations including obese hypertensives [8] and individuals with type 2 diabetes [9], both alone and in combination with other lifestyle interventions [10], with consistent results. The Optimal Macro-Nutrient Intake to Prevent Heart Disease (OmniHeart) trial 
demonstrated that within a DASH-like dietary pattern, substituting protein for carbohydrate or substituting fat (primarily monounsaturated) for carbohydrate additionally lowered blood pressure [11].

\section{Mediterranean Diet}

The Mediterranean dietary pattern has many similarities with the DASH dietary pattern but is generally higher in fat, primarily monounsaturated fat from olive oil, nuts, and seeds (commonly close to $40 \%$ of daily energy). The Prevención con Dieta Mediterránea (PREDIMED) Study examined the effects of a Mediterranean dietary pattern with extravirgin olive oil or nuts as compared to a low fat dietary pattern on cardiovascular disease $[12,13]$ and blood pressure [14] among 772 men and women aged 55-80 years. Compared with the low-fat diet, the mean net changes in the Mediterranean diet with olive oil group and the Mediterranean diet with nuts group were $-5.9 \mathrm{mmHg}(\mathrm{CI},-8.7$ to $-3.1 \mathrm{mmHg}$ ) and $-7.1 \mathrm{mmHg}(\mathrm{CI},-10.0$ to $-4.1 \mathrm{mmHg}$ ), respectively, for systolic blood pressure [14]. A recent Cochrane systematic review of Mediterranean dietary patterns and cardiovascular risk factors included five trials reporting blood pressure [15•]. However, significant heterogeneity between trials precluded the pooling of results in this review. Significant reductions in blood pressure were present among three of five trials for both systolic and diastolic blood pressure. While the evidence is limited, taken as a whole, it is suggestive of a blood-pressure-lowering effect of Mediterranean style dietary patterns.

\section{Macronutrients}

Manipulations of macronutrients, including protein, fat, and carbohydrates, have been a cornerstone of strategies for weight loss and improving the cholesterol profile for many years. The evidence that particular macronutrients are also effective in reducing blood pressure is quite strong [16-18]. The largest body of evidence for any macronutrients' influence on blood pressure is that regarding protein.

\section{Protein}

A variety of studies, both observational and randomized controlled trials, have demonstrated that protein supplementation or the replacement of protein for fat or carbohydrate in an isocaloric diet results in lower blood pressures [19, 20, 21••, 22]. Observational studies have shown a strong and consistent inverse relationship between dietary protein and blood pressure [19, 20, 23-26]. In 2010, a systematic review of dietary protein and blood pressure identified 26 observational studies that examined the relationship using dietary assessment methods and/ or biomarkers of protein intake [19]. Cross-sectional studies that assessed protein intake via dietary questionnaires or interviews tended to show a weak inverse association, whereas the majority of prospective studies identified no association. Among observational studies that included a biomarker of protein intake, including the large INTERSALTand INTERMAP studies, there was a stronger and more consistent inverse association with blood pressure [19, 25-27].

Since the publication of the OmniHeart study, which showed a decrease in both systolic and diastolic blood pressure when protein was substituted for dietary carbohydrate [11],

Curr Hypertens Rep. Author manuscript; available in PMC 2015 March 19. 
additional large randomized controlled trials of protein supplementation have been published [28••, 29•], which strongly support the inverse relationship between dietary protein and blood pressure. In a 4-week parallel-group randomized clinical trial on the effects of protein supplementation on blood pressure, $60 \mathrm{~g}$ / day of protein (30\% egg protein, $30 \%$ milk protein, $20 \%$ soy protein, $20 \%$ pea protein) reduced systolic blood pressure by $4.9 \mathrm{mmHg}(p=0.005)$ and diastolic blood pressure by $2.7 \mathrm{mmHg}(p=0.05)$, as compared to $60 \mathrm{~g}$ /day of maltodextrin, among 99 overweight men and women with pre-hypertension or untreated stage I hypertension [29•]. In the Protein and Blood Pressure Study, a randomized, double-blind crossover trial among 352 adults with pre-hypertension or stage I hypertension, participants were assigned to consume $40 \mathrm{~g} /$ day soy protein supplement, milk protein supplement, or carbohydrate supplement for 8 weeks in a random order with 3-week washout periods in between [28••]. Soy and milk protein supplementation reduced systolic blood pressure by $2.0 \mathrm{mmHg}(p=0.002)$ and $2.3 \mathrm{mmHg}(p=0.0007)$, respectively. Diastolic blood pressure was also reduced, but not statistically significantly, and there were no differences in blood pressure reductions according to the type of protein supplement.

These well-controlled short-term trials have demonstrated a consistent effect of protein supplementation on blood pressure, but longer-term data from randomized controlled trials are sparse. A 2-year double-blind, placebo-controlled, parallel-design trial investigating the effects on blood pressure of whey protein supplementation as compared to carbohydrate in 219 women between 70 and 80 years of age was conducted by Hodgson and colleagues [30]. Relative to control, the estimated mean net differences in protein and carbohydrate intakes were 18 and $-22 \mathrm{~g} /$ day at year 1 and 22 and $-18 \mathrm{~g} /$ day at year 2 . No significant differences in blood pressure between groups were found. Unfortunately, this trial is not closely comparable to the recent short-term trials because the dose of protein supplementation (and carbohydrate control) was much lower, on average $20 \mathrm{~g} / \mathrm{day}$ as compared to $40 \mathrm{or} 60 \mathrm{~g} /$ day; more than half of participants were taking antihypertensive medications concomitantly; and the population demographics were quite different (70-80-year-old women only in the latter study).

Several recent meta-analyses and systematic reviews of randomized controlled trials have also supported a blood pressure-lowering effect of dietary protein intake, reaching similar conclusions $[19,21 \bullet \bullet, 22,29 \bullet]$. Increased protein intake significantly reduced blood pressure compared to carbohydrates, but there was no significant difference in blood pressure reduction between animal and vegetable protein sources.

The exact mechanisms relating dietary protein intake to blood pressure remain unclear, although several have been proposed [29•, 31, 32]. Increases in dietary protein intake may impact plasma amino acid concentrations, which in turn may affect blood pressure regulation [32]. For instance, cysteine, glutamate, arginine, leucine, taurine, and tryptophan have all been suggested to have blood pressure-lowering effects through their influence on processes and metabolites including insulin resistance, advanced glycation end products, oxidative stress, renal function, nitric oxide bioavailability, and the renin-angiotensin aldosterone system [32]. L-arginine in particular has been implicated in blood pressure lowering as a substrate of nitric oxide synthase, and evidence from supplementation trials suggests a potential role for this amino acid [33]. Despite the lack of a clear mechanism, 
clinical trials have shown consistent evidence of the safety and efficacy of dietary protein supplementation such that health care providers should consider advising their patients with pre-hypertension or untreated stage I hypertension to replace carbohydrates with protein as part of a dietary strategy to prevent and treat hypertension.

\section{Fats}

Given the long history of the diet-heart hypothesis, dietary fats have also been a focus of investigation in the area of hypertension and blood pressure [34]. Total dietary fat intake includes intakes of saturated, omega-3 polyunsaturated, omega- 6 poly-unsaturated, and monounsaturated fatty acids. There has been great interest in the possible effects of monounsaturated fats and omega-3 polyunsaturated fatty acids in regulating blood pressure $[35,36]$. The OmniHeart trial demonstrated that partial replacement of carbohydrate with dietary fat (37\% of daily energy from total fat with $21 \%$ from monounsaturated fat), primarily olive and canola oils, reduced systolic blood pressure by $2.9 \mathrm{mmHg}$ [11]. A recent meta-analysis examining the effect of monounsaturated fats on blood pressure included nine randomized controlled trials of high monounsaturated fat diets and concluded that systolic (pooled mean net change: $-2.26 \mathrm{mmHg}, 95 \% \mathrm{CI}:-4.28,-0.25$ ) and diastolic (pooled mean net change: $-1.15 \mathrm{mmHg}, 95 \% \mathrm{CI}:-1.96,-0.34$ ) blood pressure reductions were significantly greater among participants assigned to these diets than for those assigned to control diets [36]. The evidence of the effects of omega-3 fats from fish oils on blood pressure is also generally consistent with at least five meta-analyses finding statistically significant reductions in blood pressure [37-39, 40•, 41]. The most recent of these analyses focused exclusively on fish oil supplementation and included 17 randomized controlled trials, with a total of 1,524 participants. The authors found a statistically significant reduction in systolic and diastolic blood pressure $(-2.56 \mathrm{mmHg}$ and $-1.47 \mathrm{mmHg}$, respectively) among the eight trials including hypertensive participants, but a nonsignificant reduction in both systolic and diastolic blood pressure among the nine studies that included normotensive participants [40•]. Two meta-analyses that focused exclusively on the effect of fish oil supplementation on blood pressure in patients with type 2 diabetes had inconsistent findings $[42,43]$.

\section{Micronutrients}

\section{Sodium}

Sodium is ubiquitous among most foods and beverages. Therefore, the amount of sodium intake among a population is primarily dictated by a complex interaction of cultural context and dietary habits [44]. Sodium is a main chemical component in common table salt, but only $11 \%$ of sodium intake in the US is attributable to salt added during cooking or at the table [45]. In contrast, the majority comes from processed foods. The average self-reported daily sodium intake for Americans aged 2 years and older is $3.6 \mathrm{~g}$ (equivalent to approximately $9.4 \mathrm{~g}$ salt/day as sodium chloride) [46, 47]. These levels are in excess of the 2 $\mathrm{g} /$ day (equivalent to $5 \mathrm{~g} /$ day of salt) recommended by World Health Organization (WHO) or $2.3 \mathrm{~g} /$ day recommended by the Institute of Medicine (IOM) as a tolerable upper intake level $[48,49]$.

Curr Hypertens Rep. Author manuscript; available in PMC 2015 March 19. 
To improve blood pressure control, the American Society of Hypertension (ASH) and the 2010 Dietary Guidelines for Americans recommended reducing sodium intake to a goal of $<2,300 \mathrm{mg}$ /day in the general population and a lower goal of $<1,500 \mathrm{mg} /$ day for populations predisposed to salt sensitivity: African Americans, middle- and older-aged persons, and individuals with hypertension, diabetes, or chronic kidney disease [50, 51]. However, there is significant difficulty in achieving these dietary sodium reductions. Furthermore, there is an unequal probability of adherence to reducing dietary sodium with respect to sex and race suggested by studies using sodium excretion as an index of sodium intakes [52]. This leads many to entertain the strategy by which sodium reduction may be accomplished. With the predominance of dietary sodium derived from processed foods, organizations such as the American Heart Association (AHA), American Medical Association (AMA), American Public Health Association (APHA), and IOM advocate government-sponsored requirements for food producers to reduce salt content incrementally over 5-10 years [53, 54]. Those advocating such interventions note existing programs in Finland, the UK, Ireland, Australia, and New Zealand [45]. The benefits of overcoming the difficulties to reduce sodium intake are compelled by predicted reduction of mortality and morbidity as well as significant savings in health care costs similar to those observed in Canada and Norway [55].

The evidence that dietary sodium and blood pressure are positively linked is strong and consistent and includes results from a large number of randomized controlled trials. The well-known DASH and DASH-Sodium trials demonstrated the effects of a DASH diet as compared to a typical American diet at $3.6 \mathrm{~g} / \mathrm{day}, 2.3 \mathrm{~g} / \mathrm{day}$, and $1.2 \mathrm{~g} /$ day of sodium, with progressively lower blood pressure results [56, 57]. A recent meta-analysis of 37 randomized controlled trials also demonstrates the strong and consistent relationship that has been observed between dietary sodium and blood pressure [44].

Some lines of evidence have also suggested targeting sodium reduction to $<1.5 \mathrm{~g} /$ day among those who may be particularly sensitive to sodium [56, 58, 59]. In contrast, the recent IOM Report, Sodium Intake in Populations: Assessment of Evidence, commissioned by the Centers for Disease Control and Prevention (CDC) to review evidence from recent studies examining the effects of sodium on clinical events rather than blood pressure as a surrogate endpoint, concluded that there was insufficient evidence of benefit and some evidence suggesting risk of adverse outcomes associated with sodium intake $<2.3 \mathrm{~g}$ /day [48]. This report indicated that studies with clinical events as the outcome were too few and of inconsistent quality to conclude that lowering sodium intake to $<2.3 \mathrm{~g} /$ day either increased or decreased the risk of heart disease, stroke, or all-cause mortality in the general US population, and it suggested a higher risk of adverse health outcomes among those with midto late-stage heart failure receiving aggressive medical treatment. Consistent with these conclusions, a meta-analysis of short-term studies found that, on average, 2-weeks of dietary sodium restriction to $<1.5 \mathrm{~g} /$ day increased renin, aldosterone, catecholamines, and lipids [60]. In opposition to the conclusions of the IOM report, the AHA issued its 2012 Presidential Advisory, Sodium, Blood Pressure, and Cardiovascular Disease: Further Evidence Supporting the American Heart Association Sodium Reduction Recommendations, suggesting that recommendations for sodium reduction to $1.5 \mathrm{~g} / \mathrm{day}$ in specific populations should persist based on evidence of improved blood pressure reduction [61]. 
Introduction of the DASH diet saw greater blood pressure effects at higher than lower sodium intakes, raising the question of whether increased potassium intake could be responsible for such findings [56]. Indeed, potassium supplementation reduces blood pressure substantially in hypertensive patients with salt-rich diets [62]. ASH and IOM recommend daily potassium intake of $4.7 \mathrm{~g}$ as a dietary approach to lowering blood pressure $[48,50]$. Unfortunately, the prevailing Western dietary pattern is dominated by prepared foods high in sodium and drastically less in potassium-rich fruits and vegetables, diametrically opposite of the recommendations [63].

Despite these realities, a well-established body of evidence demonstrates that a variety of potassium intake goals reduces blood pressure. Based on estimates from the INTERSALT study, a $0.6 \mathrm{~g} /$ day increase in potassium intake results in a $1.0 \mathrm{mmHg}$ reduction in systolic blood pressure and is consistent with the daily potassium supplementation of $51 \mathrm{mmol}$ (nearly $2 \mathrm{~g}$ ) resulting in a 3.3 and $2.1 \mathrm{mmHg}$ reduction of systolic and diastolic blood pressure, respectively $[58,64]$.

Blood pressure responses to dietary potassium interventions have been examined in a variety of populations. The largest controlled feeding study of potassium supplementation effects on blood pressure was conducted among Chinese adults [65] and demonstrated a significant reduction in blood pressures that was reproducible after an average of 4.5 years [64]. Variations in baseline blood pressure appear to influence responses to potassium supplementation. Increased potassium intake reduces blood pressure in hypertensives more than nonhypertensives [58, 66]. Some studies have also suggested that blood pressure in African Americans may be particularly affected by potassium intake or lack thereof. African Americans have higher blood pressure at lesser degrees of potassium-deficiency and show greater blood pressure lowering when potassium is replete, particularly in the context of high salt intake [67]. In a cross-sectional study of 3,303 participants, blood pressure was higher in African Americans than non-African Americans for any given value of urinary sodium to potassium ratio, and men had larger increases in diastolic blood pressure per 3unit increase in the urinary sodium-to-potassium ratio than women [68].

Many explanations have been offered to elucidate the blood pressure-lowering effect of increased dietary potassium including decreased vascular smooth muscle contraction by either by altering the membrane potential [69] or restoring endothelium-dependent vasorelaxation [70]. On the other hand, failure of the kidney to adapt to a diet lower in potassium has been linked to dysregulated sodium retention and development of hypertension [63]. Intrarenal ion abundance and hormone activity have been identified as potential mediators of potassium effects. Potassium-mediated blood pressure reductions have implicated ROMK in a uninephrectomized salt-sensitive animal model of hypertension [71] and in human AQP2, sodium-hydrogen exchanger type 3 [72], and sodium chloride cotransporter [73], causing a thiazide-like effect [74]. Potassium regulation of ion channel activity is heavily influenced by hormonal systems with the renin-angiotensin-aldosterone system chief among them [75]. Additionally, genetic variations in the renin-angiotensinaldosterone system play an important role in determining individual blood pressure responses to dietary potassium intake [76]. 


\section{Magnesium}

Magnesium is the second most abundant intracellular cation in humans, and dietary repletion is generally facilitated by small intestinal absorption [77]. Repletion is favored by the wide availability of foods high in magnesium concentrations, including leafy vegetables, nuts, whole grains, fruits, and legumes [78]. As the typical Western diet is deficient in these magnesium-rich foods, low-concentration dietary magnesium supplementation can be accomplished with multivitamin injections, over the counter laxatives, or a number of oral magnesium preparations, of which magnesium gluconate has the greatest bioavailability [79].

Magnesium as a potential dietary antihypertensive has been investigated in numerous studies; however, many studies have failed to find an effect of magnesium on blood pressure. In a prospective evaluation of 41,541 women of the Nurse's Health Study, magnesium intake $>0.35 \mathrm{~g} /$ day showed blood pressure reductions of $-1.3 /-1 \mathrm{mmHg}$ compared with intake $<0.2 \mathrm{~g} /$ day [80]. Even more encouraging are the results of magnesium supplements decreasing systolic and diastolic blood pressure 3 to $4 \mathrm{mmHg}$ and 2 to 3 $\mathrm{mmHg}$, respectively, with greater dose-dependent effects at supplementations $>370 \mathrm{mg} /$ day $[79,81,82]$.

There is an emerging recognition of magnesium as a potential adjuvant for other nutrients currently recognized for their antihypertensive effect, namely potassium. When compared to persons using regular table salt as a seasoning, ingestion of a "Smart Salt," composed of 50 $\%$ sodium chloride, $25 \%$ potassium chloride, and $25 \%$ magnesium ammonium potassium chloride, led to significantly lower blood pressure over 8 weeks [83].

\section{Other Dietary Factors}

\section{Alcohol}

It is well established that excessive alcohol consumption is associated with elevated blood pressure and the development of hypertension [50, 84]. In a 2001 meta-analysis of 15 randomized controlled trials of alcohol reduction interventions, Xin et al. reported a doseresponse relationship between alcohol reduction and blood pressure reduction. An average $67 \%$ reduction in alcohol consumption resulted in significant reductions in mean systolic and diastolic blood pressures of 3.3 and $2.0 \mathrm{mmHg}$, respectively [85]. In a recent analysis of the 1999-2004 National Health and Nutrition Examination Survey that included adults aged 20-84 years who were free of cardiovascular disease and hypertension, alcohol consumption above recommended guidelines (more than 2 drinks per day in men and 1 drink per day in women) $[50,51]$ was associated with higher systolic blood pressure in both men and women $[86 \bullet]$.

The association between blood pressure and low to moderate levels of alcohol consumption is less clear. Observational cohort and cross-sectional studies have reported linear, J-shaped, or a threshold association between alcohol consumption and blood pressure [87-89]. Furthermore, the relationship between alcohol consumption and blood pressure may vary by gender, race/ethnicity, or presence of comorbidities [89, 90•, 91, 92]; thus, the recommendations may not be appropriate for all subgroups of the population. Sesso and 
colleagues prospectively followed 28,848 women from the Women's Health Study and 13,455 men from the Physicians' Health Study who were free of cardiovascular disease and hypertension and found that low to moderate alcohol consumption decreased the risk of hypertension in women and increased the risk in men [92]. Alcohol consumption of four or more drinks/day in women was associated with hypertension, while consumption of just one or more drinks/day in men was associated with hypertension risk [92]. The Atherosclerosis Risk in Communities (ARIC) study demonstrated that moderate alcohol consumption among blacks but not whites was associated with increased risk of hypertension [89]. In the Reasons for Geographic and Racial Differences in Stroke (REGARDS) study, a national cohort of blacks and whites, heavy alcohol consumption was significantly associated with increased systolic blood pressure and a higher prevalence of hypertension. The association between alcohol consumption and hypertension was stronger among individuals who had diabetes than those without diabetes [90•].

\section{Fiber}

Dietary fiber includes soluble and insoluble components of food from plants that are indigestible. US Dietary Guidelines recommend $25-30 \mathrm{~g} /$ day of fiber from foods. However, fiber intake in the US and many other Western countries is only half that at $15 \mathrm{~g} /$ day [51]. There is strong evidence that dietary fiber reduces cholesterol and potentially reduces the risk of heart disease, but the evidence to support an association with hypertension is insufficient to warrant any recommendations [51, 93, 94].

Fiber intake and blood pressure have been reported to be inversely related [95, 96]. He and colleagues conducted a randomized controlled trial in 110 adults to determine the efficacy of water-soluble fiber intake [97]. Participants were randomly assigned to either a high or low fiber diet for 12 weeks. Although the net change in blood pressure between the two diets was not statistically significant, mean systolic and diastolic blood pressures were significantly reduced by 3.4 and $2.2 \mathrm{mmHg}$, respectively, in the high fiber group. In a comprehensive meta-analysis of 25 randomized controlled trials conducted in 1,477 individuals, Whelton and colleagues reported that fiber intake caused a modest reduction in diastolic blood pressure $(-1.65 \mathrm{mmHg}, 95 \% \mathrm{CI},-2.70$ to -0.61$)$ but had no association with systolic blood pressure [98]. Fiber intake may have a greater effect on blood pressure in individuals with hypertension $[96,98]$. In subgroup analyses involving five trials conducted among hypertensives, fiber intake significantly reduced both systolic and diastolic blood pressure by 5.95 and $4.20 \mathrm{mmHg}$, respectively [98].

\section{Conclusions}

Dietary approaches to modify blood pressure should be an important strategy of cardiovascular health promotion. There is extensive literature demonstrating that multiple individual dietary components and several dietary patterns affect blood pressure. The strongest evidence for lowering blood pressure or preventing hypertension through dietary intervention includes adopting a dietary pattern such as the DASH diet or a Mediterranean diet, eating less saturated fat and total fat, getting plenty of potassium, limiting the amount of sodium in the diet, and limiting alcohol consumption. It is likely that other dietary factors, 
such as magnesium and fiber, may affect blood pressure, but the current evidence to support their recommendation is unsubstantiated. Additional research that includes population subgroups and explores the role of other nutrient factors, functional foods, and dietary patterns in preventing hypertension is warranted. Despite the proven benefits of a dietary pattern, there are many cultural and societal forces and commercial interests that have an impact on whether people adopt and follow such a diet. Effective clinical and public health interventions that incorporate individual behavior changes that lead to sustained dietary changes and environmental changes that encourage and promote greater access to healthy food choices are needed.

\section{References}

Papers of particular interest, published recently, have been highlighted as:

- Of importance

•• Of major importance

1. Go AS, Mozaffarian D, Roger VL, Benjamin EJ, Berry JD, Borden WB, et al. Heart Disease and Stroke Statistics-2013 update: a report from the American Heart Association. Circulation. 2013; 127(1):e6-e245.10.1161/CIR.0b013e31828124ad [PubMed: 23239837]

2. Krousel-Wood MA, Muntner P, He J, Whelton PK. Primary prevention of essential hypertension. Med Clin North Am. 2004; 88(1):223-38. [PubMed: 14871061]

3. Hsiao CJ, Cherry DK, Beatty PC, Rechtsteiner EA. National Ambulatory Medical Care Survey: 2007 summary. Natl Health Stat Rep. 2007; 2010(27):1-32.

4. Whelton PK, He J, Appel LJ, Cutler JA, Havas S, Kotchen TA, et al. Primary prevention of hypertension: clinical and public health advisory from The National High Blood Pressure Education Program. JAMA. 2002; 288(15):1882-8. [PubMed: 12377087]

5. Cook NR, Cohen J, Hebert PR, Taylor JO, Hennekens CH. Implications of small reductions in diastolic blood pressure for primary prevention. Arch Int Med. 1995; 155(7):701-9. [PubMed: 7695458]

6. Appel LJ, Moore TJ, Obarzanek E, Vollmer WM, Svetkey LP, Sacks FM, et al. A clinical trial of the effects of dietary patterns on blood pressure. DASH Collaborative Research Group. NEJM. 1997; 336(16):1117-24.10.1056/NEJM199704173361601 [PubMed: 9099655]

7. Svetkey LP, Simons-Morton D, Vollmer WM, Appel LJ, Conlin PR, Ryan DH, et al. Effects of dietary patterns on blood pressure: subgroup analysis of the Dietary Approaches to Stop Hypertension (DASH) randomized clinical trial. Arch Inter Med. 1999; 159(3):285-93.

8. Al-Solaiman Y, Jesri A, Mountford WK, Lackland DT, Zhao Y, Egan BM. DASH lowers blood pressure in obese hypertensives beyond potassium, magnesium and fibre. J Hum Hypertens. 2010; 24(4):237-46.10.1038/jhh.2009.58 [PubMed: 19626043]

9. Azadbakht L, Fard NR, Karimi M, Baghaei MH, Surkan PJ, Rahimi M, et al. Effects of the Dietary Approaches to Stop Hypertension (DASH) eating plan on cardiovascular risks among type 2 diabetic patients: a randomized crossover clinical trial. Diabetes Care. 2011; 34(1):55-7.10.2337/ dc10-0676 [PubMed: 20843978]

10. Appel LJ, Champagne CM, Harsha DW, Cooper LS, Obarzanek E, Elmer PJ, et al. Effects of comprehensive lifestyle modification on blood pressure control: main results of the PREMIER clinical trial. JAMA. 2003; 289(16):2083-93.10.1001/jama.289.16.2083 [PubMed: 12709466]

11. Appel LJ, Sacks FM, Carey VJ, Obarzanek E, Swain JF, Miller ER 3rd, et al. Effects of protein, monounsaturated fat, and carbohydrate intake on blood pressure and serum lipids: results of the OmniHeart randomized trial. JAMA. 2005; 294(19):2455-64.10.1001/jama.294.19.2455 [PubMed: 16287956] 
12. Estruch R, Ros E, Martinez-Gonzalez MA. Mediterranean diet for primary prevention of cardiovascular disease. NEJM. 2013; 369(7):676-7.10.1056/NEJMc1306659 [PubMed: 23944307]

13. Estruch R, Ros E, Salas-Salvado J, Covas MI, Corella D, Aros F, et al. Primary prevention of cardiovascular disease with a Mediterranean diet. NEJM. 2013; 368(14):1279-90.10.1056/ NEJMoa1200303 [PubMed: 23432189]

14. Estruch R, Martinez-Gonzalez MA, Corella D, Salas-Salvado J, Ruiz-Gutierrez V, Covas MI, et al. Effects of a Mediterranean-style diet on cardiovascular risk factors: a randomized trial. Ann Intern Med. 2006; 145(1):1-11. [PubMed: 16818923]

15•. Rees K, Hartley L, Flowers N, Clarke A, Hooper L, Thorogood M, et al. 'Mediterranean' dietary pattern for the primary prevention of cardiovascular disease. Cochrane Database Syst Rev. 2013; 8:CD009825. A systematic review and meta-analysis evaluating the effects of a Mediterranean style dietary pattern on blood pressure reduction among other cardiovascular risk factors. 10.1002/14651858.CD009825.pub2 [PubMed: 23939686]

16. Mohanlal V, Parsa A, Weir MR. Role of dietary therapies in the prevention and treatment of hypertension. Nat Rev Nephrol. 2012; 8(7):413-22.10.1038/nrneph.2012.91 [PubMed: 22585275]

17. Myers VH, Champagne CM. Nutritional effects on blood pressure. Curr Opin Lipidol. 2007; 18(1): 20-4.10.1097/MOL.0b013e328012d911 [PubMed: 17218827]

18. Miller ER 3rd, Erlinger TP, Appel LJ. The effects of macronutrients on blood pressure and lipids: an overview of the DASH and OmniHeart trials. Curr Atheroscler Rep. 2006; 8(6):460-5. [PubMed: 17045071]

19. Altorf-van der Kuil W, Engberink MF, Brink EJ, van Baak MA, Bakker SJ, Navis G, et al. Dietary protein and blood pressure: a systematic review. PLoS One. 2010; 5(8):e12102.10.1371/ journal.pone.0012102 [PubMed: 20711407]

20. Obarzanek E, Velletri PA, Cutler JA. Dietary protein and blood pressure. JAMA. 1996; 275(20): 1598-603. [PubMed: 8622252]

21••. Rebholz CM, Friedman EE, Powers LJ, Arroyave WD, He J, Kelly TN. Dietary protein intake and blood pressure: a meta-analysis of randomized controlled trials. Am J Epidemiol. 2012; 176 (Suppl 7):S27-43. This meta-analysis updates completed and ongoing randomized controlled clinical trials of protein supplementation and blood pressure reduction. 10.1093/aje/kws245 [PubMed: 23035142]

22. Tielemans SM, Altorf-vanderKuil W, Engberink MF, Brink EJ, van Baak MA, Bakker SJ, et al. Intake of total protein, plant protein and animal protein in relation to blood pressure: a metaanalysis of observational and intervention studies. J Hum Hypertens. 2013; 27(9):564-71.10.1038/ jhh.2013.16 [PubMed: 23514841]

23. He J, Whelton PK. Effect of dietary fiber and protein intake on blood pressure: a review of epidemiologic evidence. Clin Exp Hypertens. 1999; 21(5-6):785-96. [PubMed: 10423101]

24. Liu L, Ikeda K, Sullivan DH, Ling W, Yamori Y. Epidemiological evidence of the association between dietary protein intake and blood pressure: a meta-analysis of published data. Hypertens Res. 2002; 25(5):689-95. [PubMed: 12452320]

25. Stamler J, Caggiula A, Grandits GA, Kjelsberg M, Cutler JA. Relationship to blood pressure of combinations of dietary macronutrients. Findings of the Multiple Risk Factor Intervention Trial (MRFIT). Circulation. 1996; 94(10):2417-23. [PubMed: 8921782]

26. Stamler J, Elliott P, Kesteloot H, Nichols R, Claeys G, Dyer AR, et al. Inverse relation of dietary protein markers with blood pressure. Findings for 10,020 men and women in the INTERSALT Study. INTERSALT Cooperative Research Group. INTERnational study of SALT and blood pressure. Circulation. 1996; 94(7):1629-34. [PubMed: 8840854]

27. Elliott P, Stamler J, Dyer AR, Appel L, Dennis B, Kesteloot H, et al. Association between protein intake and blood pressure: the INTERMAP Study. Arch Int Med. 2006; 166(1):79-87.10.1001/ archinte.166.1.79 [PubMed: 16401814]

28••. He J, Wofford MR, Reynolds K, Chen J, Chen CS, Myers L, et al. Effect of dietary protein supplementation on blood pressure: a randomized, controlled trial. Circulation. 2011; 124(5): 589-95. A three-phase randomized controlled cross-over trial documenting the efficacy of dietary protein supplementation from plant (soy) and animal (milk) sources as compared to 
carbohydrate control for blood pressure reduction. There were no differences between protein source and blood pressure reduction. 10.1161/CIRCULATIONAHA.110.009159 [PubMed: 21768541]

29. Teunissen-Beekman KF, van Baak MA. The role of dietary protein in blood pressure regulation. Curr Opin Lipidol. 2013; 24(1):65-70. A randomized controlled parallel group trial documenting the efficacy of protein supplementation (blend of plant and animal sources) as compared to carbohydrate control for blood pressure reduction. 10.1097/MOL.0b013e32835b4645 [PubMed: 23165085]

30. Hodgson JM, Zhu K, Lewis JR, Kerr D, Meng X, Solah V, et al. Long-term effects of a proteinenriched diet on blood pressure in older women. Br J Nutr. 2012; 107(11):1664-72.10.1017/ S0007114511004740 [PubMed: 21910947]

31. Wang YF, Yancy WS Jr, Yu D, Champagne C, Appel LJ, Lin PH. The relationship between dietary protein intake and blood pressure: results from the PREMIER study. J Hum Hypertens. 2008; 22(11):745-54.10.1038/jhh.2008.64 [PubMed: 18580887]

32. Vasdev S, Stuckless J. Antihypertensive effects of dietary protein and its mechanism. Int J Angiol. 2010; 19(1):e7-e20. [PubMed: 22477579]

33. Dong JY, Qin LQ, Zhang Z, Zhao Y, Wang J, Arigoni F, et al. Effect of oral L-arginine supplementation on blood pressure: a meta-analysis of randomized, double-blind, placebocontrolled trials. Am Heart J. 2011; 162(6):959-65.10.1016/j.ahj.2011.09.012 [PubMed: 22137067]

34. Hall WL. Dietary saturated and unsaturated fats as determinants of blood pressure and vascular function. Nutr Res Rev. 2009; 22(1):18-38.10.1017/S095442240925846X [PubMed: 19243668]

35. Cabo J, Alonso R, Mata P. Omega-3 fatty acids and blood pressure. Br J Nutr. 2012; 107 (Suppl 2):S195-200.10.1017/S0007114512001584 [PubMed: 22591893]

36. Schwingshackl L, Strasser B, Hoffmann G. Effects of monounsaturated fatty acids on cardiovascular risk factors: a systematic review and meta-analysis. Ann Nutr Metab. 2011; 59(24):176-86.10.1159/000334071 [PubMed: 22142965]

37. Dickinson HO, Nicolson DJ, Cook JV, Campbell F, Beyer FR, Ford GA, et al. Calcium supplementation for the management of primary hypertension in adults. Cochrane Database Syst Rev. 2006; 2:CD004639.10.1002/14651858.CD004639.pub2 [PubMed: 16625609]

38. Geleijnse JM, Giltay EJ, Grobbee DE, Donders AR, Kok FJ. Blood pressure response to fish oil supplementation: metaregression analysis of randomized trials. J Hypertens. 2002; 20(8):1493-9. [PubMed: 12172309]

39. Appel LJ, Miller ER 3rd, Seidler AJ, Whelton PK. Does supplementation of diet with 'fish oil' reduce blood pressure? A meta-analysis of controlled clinical trials. Arch Intern Med. 1993; 153(12):1429-38. [PubMed: 8141868]

40•. Campbell F, Dickinson HO, Critchley JA, Ford GA, Bradburn M. A systematic review of fish-oil supplements for the prevention and treatment of hypertension. Eur J Prevent Cardiol. 2013; 20(1):107-20. A systematic review and meta-analysis of 17 studies examining the effects of omega-3 fatty acid supplementation on blood pressure. A statistically significant reduction in systolic and diastolic blood pressure was observed in the eight trials that included hypertensive participants, but a nonsignificant reduction in both systolic and diastolic blood pressure was observed among the nine studies that included normotensive participants. $10.1177 / 2047487312437056$

41. Morris MC, Sacks F, Rosner B. Does fish oil lower blood pressure? A meta-analysis of controlled trials. Circulation. 1993; 88(2):523-33. [PubMed: 8339414]

42. Hartweg J, Farmer AJ, Holman RR, Neil A. Potential impact of omega-3 treatment on cardiovascular disease in type 2 diabetes. Curr Opin Lipidol. 2009; 20(1):30-8. [PubMed: 19133409]

43. Hartweg J, Farmer AJ, Perera R, Holman RR, Neil HA. Meta-analysis of the effects of n-3 polyunsaturated fatty acids on lipoproteins and other emerging lipid cardiovascular risk markers in patients with type 2 diabetes. Diabetologia. 2007; 50(8):1593-602.10.1007/s00125-007-0695-z [PubMed: 17541540] 
44. Aburto NJ, Ziolkovska A, Hooper L, Elliott P, Cappuccio FP, Meerpohl JJ. Effect of lower sodium intake on health: systematic review and meta-analyses. BMJ. 2013; 346:f1326.10.1136/bmj.f1326 [PubMed: 23558163]

45. Havas S, Dickinson BD, Wilson M. The urgent need to reduce sodium consumption. JAMA. 2007; 298(12):1439-41.10.1001/jama.298.12.1439 [PubMed: 17895460]

46. Centers for Disease C and Prevention. Application of lower sodium intake recommendations to adults-United States, 1999-2006. MMWR Morb Mortal Wkly Rep. 2009; 58(11):281-3. [PubMed: 19325529]

47. He FJ, MacGregor GA. Effect of longer-term modest salt reduction on blood pressure. Cochrane Database Syst Rev. 2004; 3:CD004937.10.1002/14651858.CD004937 [PubMed: 15266549]

48. IOM (Institute of Medicine). Sodium intake in populations: Assessment of evidence. Washington: The National Academies Press; 2013.

49. WHO. Guideline: sodium intake for adults and children. Geneva: World Health Organization (WHO); 2012.

50. Appel LJ. American Society of Hypertension Writing G. ASH position paper: dietary approaches to lower blood pressure. J Am Soc Hypertens. 2009; 3(5):321-31.10.1016/j.jash.2009.08.003 [PubMed: 20409975]

51. Dietary Guidelines Advisory Committee. Report of the Dietary Guidelines Advisory Committee on the Dietary Guidelines for Americans, 2010, to the Secretary of Agriculture and the Secretary of Health and Human Services. Washington, DC: Agricultural Research Service;

52. Kumanyika SK, Hebert PR, Cutler JA, Lasser VI, Sugars CP, Steffen-Batey L, et al. Feasibility and efficacy of sodium reduction in the Trials of Hypertension Prevention, phase I. Trials of Hypertension Prevention Collaborative Research Group. Hypertens. 1993; 22(4):502-12.

53. Appel LJ, Frohlich ED, Hall JE, Pearson TA, Sacco RL, Seals DR, et al. The importance of population-wide sodium reduction as a means to prevent cardiovascular disease and stroke: a call to action from the American Heart Association. Circulation. 2011; 123(10):1138-43.10.1161/CIR. 0b013e31820d0793 [PubMed: 21233236]

54. Dickinson BD, Havas S. Council on S, Public Health AMA. Reducing the population burden of cardiovascular disease by reducing sodium intake: a report of the Council on Science and Public Health. Arch Int Med. 2007; 167(14):1460-8.10.1001/archinte.167.14.1460 [PubMed: 17646599]

55. Frisoli TM, Schmieder RE, Grodzicki T, Messerli FH. Salt and hypertension: is salt dietary reduction worth the effort? Am J Med. 2012; 125(5):433-9.10.1016/j.amjmed.2011.10.023 [PubMed: 22482843]

56. Sacks FM, Svetkey LP, Vollmer WM, Appel LJ, Bray GA, Harsha D, et al. Effects on blood pressure of reduced dietary sodium and the Dietary Approaches to Stop Hypertension (DASH) diet. DASH-Sodium Collaborative Research Group. NEJM. 2001; 344(1):3-10.10.1056/ NEJM200101043440101 [PubMed: 11136953]

57. Bray GA, Vollmer WM, Sacks FM, Obarzanek E, Svetkey LP, Appel LJ, et al. A further subgroup analysis of the effects of the DASH diet and three dietary sodium levels on blood pressure: results of the DASH-Sodium Trial. Am J Cardiol. 2004; 94(2):222-7.10.1016/j.amjcard.2004.03.070 [PubMed: 15246908]

58. Geleijnse JM, Kok FJ, Grobbee DE. Blood pressure response to changes in sodium and potassium intake: a metaregression analysis of randomised trials. J Hum Hypertens. 2003; 17(7):47180.10.1038/sj.jhh.1001575 [PubMed: 12821954]

59. He FJ, Li J, Macgregor GA. Effect of longer term modest salt reduction on blood pressure: cochrane systematic review and meta-analysis of randomised trials. BMJ. 2013; 346:f1325.10.1136/bmj.f1325 [PubMed: 23558162]

60. Graudal NA, Hubeck-Graudal T, Jurgens G. Effects of low sodium diet versus high sodium diet on blood pressure, renin, aldosterone, catecholamines, cholesterol, and triglyceride. Cochrane Database Syst Rev. 2011; 11:CD004022.10.1002/14651858.CD004022.pub3 [PubMed: 22071811]

61. Whelton PK, Appel LJ, Sacco RL, Anderson CA, Antman EM, Campbell N, et al. Sodium, blood pressure, and cardiovascular disease: further evidence supporting the American Heart Association 
sodium reduction recommendations. Circulation. 2012; 126(24):2880-9.10.1161/CIR. 0b013e318279acbf [PubMed: 23124030]

62. van Bommel E, Cleophas T. Potassium treatment for hypertension in patients with high salt intake: a meta-analysis. Int J Clin Pharmacol Ther. 2012; 50(7):478-82.10.5414/CP201724 [PubMed: 22541753]

63. Adrogue HJ, Madias NE. Sodium and potassium in the pathogenesis of hypertension. NEJM. 2007; 356(19):1966-78.10.1056/NEJMra064486 [PubMed: 17494929]

64. Dyer AR, Elliott P, Shipley M. Urinary electrolyte excretion in 24 hours and blood pressure in the INTERSALT Study. II. Estimates of electrolyte-blood pressure associations corrected for regression dilution bias. The INTERSALT Cooperative Research Group. Am J Epidemiol. 1994; 139(9):940-51. [PubMed: 8166144]

65. Gu D, Zhao Q, Chen J, Chen JC, Huang J, Bazzano LA, et al. Reproducibility of blood pressure responses to dietary sodium and potassium interventions: the GenSalt Study. Hypertens. 2013; 62(3):499-505.10.1161/HYPERTENSIONAHA.113.01034

66. Aburto NJ, Hanson S, Gutierrez H, Hooper L, Elliott P, Cappuccio FP. Effect of increased potassium intake on cardiovascular risk factors and disease: systematic review and meta-analyses. BMJ. 2013; 346:f1378.10.1136/bmj.f1378 [PubMed: 23558164]

67. Morris RC Jr, Sebastian A, Forman A, Tanaka M, Schmidlin O. Normotensive salt sensitivity: effects of race and dietary potassium. Hypertens. 1999; 33(1):18-23.

68. Hedayati SS, Minhajuddin AT, Ijaz A, Moe OW, Elsayed EF, Reilly RF, et al. Association of urinary sodium/potassium ratio with blood pressure: sex and racial differences. Clin J Am Soc Nephrol. 2012; 7(2):315-22.10.2215/CJN.02060311 [PubMed: 22114147]

69. Castaneda-Bueno M, Arroyo JP, Gamba G. Independent regulation of $\mathrm{Na}+$ and $\mathrm{K}+$ balance by the kidney. Med Princ Pract Int J Kuwait Univ Health Sci Cent. 2012; 21(2):10114.10.1159/000332580

70. Cunha AR, Umbelino B, Correia ML, Neves MF. Magnesium and vascular changes in hypertension. Int J Hypertens. 2012; 2012:754250.10.1155/2012/754250 [PubMed: 22518291]

71. Jung JY, Kim S, Lee JW, Jung ES, Heo NJ, Son MJ, et al. Effects of potassium on expression of renal sodium transporters in salt-sensitive hypertensive rats induced by uninephrectomy. Am J Physiol Ren Physiol. 2011; 300(6):F1422-30.10.1152/ajprenal.00598.2010

72. Matthesen SK, Larsen T, Vase H, Lauridsen TG, Pedersen EB. Effect of potassium supplementation on renal tubular function, ambulatory blood pressure and pulse wave velocity in healthy humans. Scand J Clin Lab Invest. 2012; 72(1):78-86.10.3109/00365513.2011.635216 [PubMed: 22149452]

73. Vallon V, Schroth J, Lang F, Kuhl D, Uchida S. Expression and phosphorylation of the Na+-Clcotransporter NCC in vivo is regulated by dietary salt, potassium, and SGK1. Am J Physiol Ren Physiol. 2009; 297(3):F704-12.10.1152/ajprenal.00030.2009

74. Huang CL, Kuo E. Mechanisms of disease: WNK-ing at the mechanism of salt-sensitive hypertension. Nat Clin Prac Nephrol. 2007; 3(11):623-30.10.1038/ncpneph0638

75. Frindt G, Palmer LG. Effects of dietary K on cell-surface expression of renal ion channels and transporters. Am J Physiol Ren Physiol. 2010; 299(4):F890-7.10.1152/ajprenal.00323.2010

76. He J, Gu D, Kelly TN, Hixson JE, Rao DC, Jaquish CE, et al. Genetic variants in the reninangiotensin-aldosterone system and blood pressure responses to potassium intake. J Hypertens. 2011; 29(9):1719-30.10.1097/HJH.0b013e32834a4d1f [PubMed: 21799445]

77. Wester PO. Magnesium. Am J Clin Nutr. 1987; 45(5 Suppl):1305-12. [PubMed: 3578120]

78. Chacko SA, Song Y, Nathan L, Tinker L, de Boer IH, Tylavsky F, et al. Relations of dietary magnesium intake to biomarkers of inflammation and endothelial dysfunction in an ethnically diverse cohort of postmenopausal women. Diabetes Care. 2010; 33(2):304-10.10.2337/dc09-1402 [PubMed: 19903755]

79. Kupetsky-Rincon EA, Uitto J. Magnesium: novel applications in cardiovascular disease—a review of the literature. Ann Nutr Metab. 2012; 61(2):102-10.10.1159/000339380 [PubMed: 22907037]

80. Ascherio A, Hennekens C, Willett WC, Sacks F, Rosner B, Manson J, et al. Prospective study of nutritional factors, blood pressure, and hypertension among US women. Hypertens. 1996; 27(5): $1065-72$. 
81. Jee SH, Miller ER 3rd, Guallar E, Singh VK, Appel LJ, Klag MJ. The effect of magnesium supplementation on blood pressure: a meta-analysis of randomized clinical trials. Am J Hypertens. 2002; 15(8):691-6. [PubMed: 12160191]

82. Kass L, Weekes J, Carpenter L. Effect of magnesium supplementation on blood pressure: a metaanalysis. Eur J Clin Nutr. 2012; 66(4):411-8.10.1038/ejcn.2012.4 [PubMed: 22318649]

83. Sarkkinen ES, Kastarinen MJ, Niskanen TH, Karjalainen PH, Venalainen TM, Udani JK, et al. Feasibility and antihypertensive effect of replacing regular salt with mineral salt -rich in magnesium and potassium- in subjects with mildly elevated blood pressure. Nutr J. 2011; 10:88.10.1186/1475-2891-10-88 [PubMed: 21888642]

84. Chobanian AV, Bakris GL, Black HR, Cushman WC, Green LA, Izzo JL Jr, et al. Seventh report of the Joint National Committee on Prevention, Detection, Evaluation, and Treatment of High Blood Pressure. Hypertens. 2003; 42(6):1206-52.10.1161/01.HYP.0000107251.49515.c2

85. Xin X, He J, Frontini MG, Ogden LG, Motsamai OI, Whelton PK. Effects of alcohol reduction on blood pressure: a meta-analysis of randomized controlled trials. Hypertens. 2001; 38(5):1112-7.

86•. Fan AZ, Li Y, Elam-Evans LD, Balluz L. Drinking pattern and blood pressure among nonhypertensive current drinkers: findings from 1999-2004 National Health and Nutrition Examination Survey. Clin Epidemiol. 2013; 5:21-7. An analysis indicating a direct association between higher alcohol consumption and a higher prevalence of prehypertension. 10.2147/ CLEP.S12152 [PubMed: 23390368]

87. Beilin LJ, Puddey IB. Alcohol, hypertension and cardiovascular disease-implications for management. Clin Exp Hypertens. 1993; 15(6):1157-70. [PubMed: 8268882]

88. He J, Bazzano LA. Effects of lifestyle modification on treatment and prevention of hypertension. Curr Opin Nephrol Hypertens. 2000; 9(3):267-71. [PubMed: 10847328]

89. Fuchs FD, Chambless LE, Whelton PK, Nieto FJ, Heiss G. Alcohol consumption and the incidence of hypertension: The Atherosclerosis Risk in Communities Study. Hypertens. 2001; 37(5):124250.

90•. Judd SE, McClure LA, Howard VJ, Lackland DT, Halanych JH, Kabagambe EK. Heavy drinking is associated with poor blood pressure control in the REasons for Geographic and Racial Differences in Stroke (REGARDS) study. Int J Environ Res Public Health. 2011; 8(5):1601-12. This study demonstrated that diabetes and gender significantly modify the association between alcohol consumption and hypertension. 10.3390/ijerph8051601 [PubMed: 21655140]

91. Fuchs FD, Chambless LE, Folsom AR, Eigenbrodt ML, Duncan BB, Gilbert A, et al. Association between alcoholic beverage consumption and incidence of coronary heart disease in whites and blacks: the Atherosclerosis Risk in Communities Study. Am J Epidemiol. 2004; 160(5):46674.10.1093/aje/kwh229 [PubMed: 15321844]

92. Sesso HD, Cook NR, Buring JE, Manson JE, Gaziano JM. Alcohol consumption and the risk of hypertension in women and men. Hypertens. 2008; 51(4):1080-7.10.1161/ HYPERTENSIONAHA.107.104968

93. Appel LJ, Brands MW, Daniels SR, Karanja N, Elmer PJ, Sacks FM, et al. Dietary approaches to prevent and treat hypertension: a scientific statement from the American Heart Association. Hypertens. 2006; 47(2):296-308.10.1161/01.HYP.0000202568.01167.B6

94. Bazzano LA, He J, Ogden LG, Loria CM, Whelton PK, National H, et al. Dietary fiber intake and reduced risk of coronary heart disease in US men and women: the National Health and Nutrition Examination Survey I Epidemiologic Follow-up Study. Arch Int Med. 2003; 163(16):1897904.10.1001/archinte.163.16.1897 [PubMed: 12963562]

95. Burke V, Hodgson JM, Beilin LJ, Giangiulioi N, Rogers P, Puddey IB. Dietary protein and soluble fiber reduce ambulatory blood pressure in treated hypertensives. Hypertens. 2001; 38(4):821-6.

96. Streppel MT, Arends LR, van't Veer P, Grobbee DE, Geleijnse JM. Dietary fiber and blood pressure: a meta-analysis of randomized placebo-controlled trials. Arch Int Med. 2005; 165(2): 150-6.10.1001/archinte.165.2.150 [PubMed: 15668359]

97. He J, Streiffer RH, Muntner P, Krousel-Wood MA, Whelton PK. Effect of dietary fiber intake on blood pressure: a randomized, double-blind, placebo-controlled trial. J Hypertens. 2004; 22(1):7380. [PubMed: 15106797] 
98. Whelton SP, Hyre AD, Pedersen B, Yi Y, Whelton PK, He J. Effect of dietary fiber intake on blood pressure: a meta-analysis of randomized, controlled clinical trials. J Hypertens. 2005; 23(3): 475-81. [PubMed: 15716684] 